\title{
Andrological characteristics of tropical milking criollo Bulls
}

\author{
Estrella-García, Andrea G. ${ }^{1}$; Pérez-Hernández, Ponciano ${ }^{1 *}$; Canseco-Sedano, Rodolfo ${ }^{2}$; López-Ortiz, Silvia ${ }^{1}$; \\ Ahuja-Aguirre, Concepción ${ }^{2}$; Guerrero-Hernández, Jonathan ${ }^{1}$ \\ ${ }^{1}$ Colegio de Postgraduados Campus Veracruz. Carretera Federal Xalapa-Veracruz km 88.5, Tepetates, Manlio \\ Fabio Altamirano, Veracruz, México. C. P. 91690. \\ ${ }^{2}$ Universidad Veracruzana. Facultad de Medicina Veterinaria y Zootecnia. Miguel Ángel de Quevedo s/n \\ Esquina Yáñez, Colonia Unidad Veracruzana, Veracruz, Veracruz, México. C. P. 91710. \\ *Corresponding author: pperez@colpos.mx
}

\begin{abstract}
Objective: To assess the testicular and semen characteristics of Tropical Milking Criollo (CLT) bulls in the subhumid Mexican tropics.

Design/methodology/approach: Eight bulls were evaluated and distributed in two groups: G1 (n=5): young bulls and G2 (n=3): adult bulls. All bulls were managed under grazing and evaluated throughout a year. From each bull, the following measurements were taken once a month: live weight, body condition score, scrotal circumference, and testicular width, length and volume. Semen was obtained every 3 months via an artificial vagina. The evaluated semen variables were: aspect, volume, mass and individual motility, and sperm concentration and morphology.

Results: Live weight and testicular measurements linearly increased during the study in bulls from both groups. All bulls had a scrotal circumference larger than the minimum threshold value for cattle and highquality semen.

Study limitations/implications: The low availability of CLT bulls prevented the inclusion of a larger number of animals in the research. This low animal availability makes it necessary to establish standard values for testicular measurements and semen characteristics in the CLT breed in order to select the best individuals as sires and contribute to its conservation.

Findings/conclusions: The CLT bulls had good scrotal circumference and semen quality from a young age and into adulthood. These traits make CLT bulls an important alternative for livestock breeding in the tropics.
\end{abstract}

Keywords: Semen quality, scrotal circumference, semen.

Citation: Estrella-García, Andrea G., Pérez-Hernández, Ponciano, CansecoSedano, Rodolfo, López-Ortiz, Silvia, Ahuja-Del Carmen, Concepción, \& Guerrero-Hernández, Jonathan. (2021). Andrological characteristics of tropical milking criollo Bulls. Agro Productividad, 14(\#). https://doi.org/10.32854/agrop. v14i6.1930

Editor in Chief: Dr. Jorge Cadena Iñiguez

Estimated publication date: July 2021

This work is licensed under a Creative Commons Attribution-NonCommercial 4.0 International license cc) $\$$

\section{INTRODUCTION}

The testicular measurements and semen quality evaluation are essential in the assessment of the fertility of bulls. Out of the testicular measurements, the scrotal circumference (SC) is the most used, given its easy measurement, high repeatability, and high correlation with sperm concentration, semen quality, testicular size, and body weight (Martínez-Velazquez et al., 2003). Bulls with higher-than-average SC produce more semen, of better quality and reach puberty earlier (Silva et al., 2012). The live weight of the animal is positively correlated to the testicular weight, which in turn, has a high correlation with the amount of spermatic tissue and with the SC, so the SC is the basis for estimating the testicular size and selecting sires (Silva et al., 2012).

The populations of Tropical Milking Criollo cattle (CLT; Bos taurus taurus) are scarce and distributed only in certain tropical regions of Mexico (De Alba, 2011; Parra-Cortés and Magaña-Magaña, 2019). This breed is characterized by its precocity, high fertility, ease of calving, survival, resistance to diseases and ectoparasites, and longevity (De Alba, 2011; Rosendo-Ponce and Becerril-Pérez, 2015). However, little has been documented on the andrological characteristics of males in warm climate conditions; 
this is necessary to select specimens to increase their population or for crossbreeding schemes with European or Zebu breeds in the tropics, which would improve their profitability and the sustainability of the cattle herds in these regions (Parra-Cortés and Magaña-Magaña, 2019).

Although reproductive traits have been characterized in males from $B$. taurus taurus breeds in the Latin American tropics (Palmieri et al., 2004; Madrid-Bury et al., 2011), there is no information on the CLT breed, despite its importance as a dairy genotype adapted to the tropics. Therefore, the objective of this research was to assess the testicular and seminal characteristics of CLT males in the subhumid Mexican tropics.

\section{MATERIALS AND METHODS}

\section{Geographical location and characteristics of the study}

The research was conducted in a CLT cattle herd owned by the Colegio de Postgraduados, Campus Veracruz, located in the state of Veracruz, Mexico, on the central coast of the Gulf of Mexico, at latitude $19^{\circ} 16^{\prime} \mathrm{N}$ and longitude $96^{\circ} 16^{\prime} \mathrm{W}$, at 20 m altitude, with a warm sub-humid climate, mean annual temperature of $26.5^{\circ} \mathrm{C}$ and annual precipitation of $1230 \mathrm{~mm}$. The study was conducted over one year and included four periods: 1=September 22 to December 20, 2=December 21 to March 19, 3=March 20 to June 20, and $4=$ June 21 to September 21.

\section{Experimental animals and management}

Eight bulls were selected from a group of 14 CLT males, which had no sight, limbs, or reproductive problems that could affect the results of the study. The bulls were distributed in two groups according to their age: $G 1(n=5)$ : young males that at the beginning of the study were $19.3 \pm 0.4$ months old, weighed $260 \pm 9 \mathrm{~kg}$ (live weight, LW) and had body condition (BC) from 2.5 to 3.0 on a scale of 1 to 5 ( 1 =emaciated and $5=$ obese; Wildman et al., 1982); and G2 ( $=3)$ : adult males at 30.5 \pm 3.1 months old, weighing $371 \pm 29 \mathrm{~kg} \mathrm{LW}$ and with BC similar to G1. The animals grazed in paddocks of Megathyrsus maximum, Brachiaria mutica, Cynodon nlemfluensis, and Paspalum spp., at a stocking rate of $2 \mathrm{AU}^{-1}$, and did not receive feed or mineral supplementation. All males were kept together, and none had been used as sire.

\section{Live weight and body condition}

The LW of each animal was recorded at the beginning of the study and subsequently every $30 \mathrm{~d}$ for one year. The weighing was done on a commercial cattle scale, and the $\mathrm{BC}$ was visually evaluated by the same technician, using the scale from 1 to 5 described above.

\section{Testicular characteristics}

The scrotal circumference (SC), testicular width (TW), testicular length (TL), testicular volume (TV) and testicular consistency (TC) were measured in all animals at the beginning of the study and every $30 \mathrm{~d}$ thereafter. Scrotal circumference was 
measured with a scrotal tape measure; TW and TL were measured in each testicle using a vernier; and TV was calculated with the TW and TL measurements using the equation TV $=0.5236$ (TW) (TL) ${ }^{2}$ (Bailey et al., 1996). The TC was assessed by palpation of each testis, which were graded as firm or soft, and testicular tone was graded as elastic, flaccid or rigid.

\section{Seminal characteristics}

Every three months, a semen sample was collected from each animal with an artificial vagina. For semen collection, the bull was placed with a cow previously synchronized with $\mathrm{PGF}_{2} \alpha$ (20 mg dose of Lutalyse ${ }^{\circledR}$, Lab. Zoetis, USA) during the same days of the evaluation of testicular characteristics. Immediately after collection, semen volume was determined by direct observation in the collection tube, and mass (MM) and individual (IM) sperm motility were determined. To establish MM, a $10 \mu \mathrm{L}$ semen drop was placed on a slide pre-warmed to $37^{\circ} \mathrm{C}$, observed under a phase-contrast microscope (10x and 40x) and assigned a value from 0 to 100\%. To determine the IM, a $10 \mu \mathrm{L}$ drop of semen was placed between a prewarmed slide and coverslip at $37^{\circ} \mathrm{C}$, observed for progressive rectilinear motility with phase-contrast microscopy (10x and 40x) and assigned a value from 0 to 100\%. The spermatozoa concentration (SC) in the ejaculate was determined with a hemocytometer, for which $10 \mu \mathrm{L}$ of semen were diluted in $2 \mathrm{~mL}$ of formol saline solution; then, two chambers of the hemocytometer were filled and the number of spermatozoa present in five large squares in each chamber was counted using a phase-contrast microscope (40x); the total number of cells counted was multiplied by $10^{6}$ to obtain the number of spermatozoa per milliliter of semen. To determine sperm morphology, $20 \mu \mathrm{L}$ of semen were diluted in $1 \mathrm{~mL}$ of formalin-saline solution and analyzed following the criteria by Blom (1973), using a phase-contrast microscope (1000x); 400 cells were evaluated, and the percentage of abnormal cells recorded.

\section{Statistical analysis}

Descriptive statistics were used to characterize the evaluated variables. For testicular (SC and VT) and seminal characteristics (volume, MM, IM, SC and abnormal spermatozoa) descriptive statistics were performed and mean comparisons were made using Tukey's tests when significant $\mathrm{F}$ tests were detected $(\mathrm{P}<0.05)$.

\section{RESULTS AND DISCUSSION}

\section{Changes in body weight and body condition}

Weight increased in both groups of bulls and all maintained body condition from 2.0 to 2.5 (Table 1 ). At the end of the study, G1 bulls weighed $362.8 \pm 13.4 \mathrm{~kg}$ and G2 bulls weighed $451.3 \pm 22.2 \mathrm{~kg}$; during the study, G1 bulls gained $103.1 \mathrm{~kg}$ and G2 bulls $80.2 \mathrm{~kg}$.

The weight changes observed in the G2 bulls suggest a stabilization of the growth and weight of the CLT bulls between 36- and 42-months age, as suggested for other 
breeds, depending on their management (Vásquez and Arango, 2002). This will be necessary to verify in future studies with a larger number of animals.

Table 1. Age, live weight, and body condition of young (G1) and mature (G2) Tropical Milking Criollo bulls throughout the seasons.

\begin{tabular}{|c|c|c|c|c|}
\hline \multirow{2}{*}{ Group } & \multicolumn{4}{|c|}{ Time periods } \\
\hline & 1 & 2 & 3 & 4 \\
\hline \multicolumn{5}{|c|}{ Age (months)* } \\
\hline G1 & $19.3 \pm 0.4$ & $21.6 \pm 0.2$ & $24.8 \pm 0.4$ & $27.8 \pm 0.4$ \\
\hline G2 & $30.5 \pm 3.1$ & $33.3 \pm 3.1$ & $36.5 \pm 3.1$ & $39.2 \pm 3.1$ \\
\hline \multicolumn{5}{|c|}{ Live weight $(\mathrm{kg})^{*}$} \\
\hline G1 & $260 \pm 9$ & $266 \pm 9$ & $285 \pm 16$ & $363 \pm 13$ \\
\hline G2 & $371 \pm 29$ & $365 \pm 45$ & $377 \pm 67$ & $450 \pm 42$ \\
\hline \multicolumn{5}{|c|}{ Body condition } \\
\hline G1 & 2.5 & 2.5 & 2.0 & 2.5 \\
\hline G2 & 2.5 & 2.5 & 2.5 & 2.5 \\
\hline
\end{tabular}

*Mean \pm standard deviation. 1=September 22 to December 20, 2=December 21 to March 19, 3=March 20 to June 20, 4=July 21 to September 21.

\section{Testicular characteristics}

Upon palpation, all bulls had testes of firm consistency and elastic tone in all evaluations, indicating good testicular consistency. The SC linearly increased during the study in both groups, which can be attributed to weight gain and age (Table 2). An increase in SC has been reported as age advances in Zebu (Torres-Junior and Henry, 2005) and European breeds (Jiménez-Severiano, 2002).

Table 2. Testicle measures of young (G1) and mature (G2) Tropical Milking Criollo bulls, throughout the seasons.

\begin{tabular}{|c|c|c|c|c|}
\hline \multirow{2}{*}{ Group } & \multicolumn{4}{|c|}{ Time periods } \\
\hline & 1 & 2 & 3 & 4 \\
\hline \multicolumn{5}{|c|}{ Scrotal circumference $(\mathrm{mm})^{*}$} \\
\hline G1 & $29.1 \pm 0.7^{d}$ & $30.5 \pm 0.2^{c}$ & $31.5 \pm 0.5^{\mathrm{b}}$ & $32.9 \pm 0.2^{a}$ \\
\hline G2 & $32.0 \pm 1.0^{\mathrm{d}}$ & $32.8 \pm 0.7^{\mathrm{C}}$ & $33.2 \pm 0.7^{\mathrm{b}}$ & $34.9 \pm 0.5^{\mathrm{a}}$ \\
\hline \multicolumn{5}{|c|}{ Scrotal width $(\mathrm{cm})^{*}$} \\
\hline G1 & $6.1 \pm 0.3$ & $6.7 \pm 0.2$ & $7.1 \pm 0.2$ & $7.5 \pm 0.2$ \\
\hline G2 & $7.2 \pm 0.2$ & $7.6 \pm 0.6$ & $7.8 \pm 0.4$ & $8.0 \pm 0.4$ \\
\hline \multicolumn{5}{|c|}{ Scrotal length $(\mathrm{cm})^{*}$} \\
\hline G1 & $9.7 \pm 0.4$ & $9.9 \pm 0.4$ & $10.3 \pm 0.3$ & $10.2 \pm 0.4$ \\
\hline G2 & $10.5 \pm 0.7$ & $11.1 \pm 0.5$ & $11.3 \pm 0.5$ & $11.5 \pm 0.4$ \\
\hline \multicolumn{5}{|c|}{ Testicle volume $\left(\mathrm{cm}^{3}\right)^{*}$} \\
\hline G1 & $373 \pm 22^{b}$ & $426 \pm 17^{\mathrm{b}}$ & $529 \pm 26^{\mathrm{a}}$ & $567 \pm 34^{\mathrm{a}}$ \\
\hline G2 & $585 \pm 44^{b}$ & $685 \pm 43^{\mathrm{a}}$ & $708 \pm 37^{\mathrm{a}}$ & $724 \pm 31^{\mathrm{a}}$ \\
\hline
\end{tabular}


It was also observed that at $24.8 \pm 0.4$ months of age, the G1 bulls had a SC of $31.5 \pm 0.5$ $\mathrm{cm}$, slightly lower than the $32 \mathrm{~cm}$ suggested as a minimum for bulls of criollo breeds at the age of $24 \mathrm{~m}$ (Irons et al., 2007). In this regard, it is worth mentioning that the bulls used in this study are genetically small in body size, and their diet was based on low nutritional quality grass without supplement, which probably affected the SC.

The SC of the evaluated bulls at different ages was comparable to that of the horned Costeño, Romosinuano (Palmieri et al., 2004) and Guzerat (Torres-Junior and Henry, 2005) bulls, the latter with greater weight than the CLT and the Criollo Limonero (Ocanto et al., 1991; Madrid et al., 1995). However, the SC in CLT bulls was lower than that of Bos taurus indicus $\times$ Bos taurus taurus bulls (Prieto et al., 2007), with higher body weight than the CLT.

Racial differences have been noted that cause some Bos taurus taurus breeds to reach puberty at a younger age, lower weight and smaller SC than others. It has been proposed that males should be evaluated according to a minimum SC standard for the breed and not according to the one established by the Society for Theriogenology (Coulter et al., 1987). This could be applied to this study, that is, to establish a SC standard for the CLT breed in particular, because they are smaller in size and weight less than most B. taurus taurus breeds.

Like the SC, TW and TL also increased linearly throughout the evaluation in all animals (Table 2). The TW was higher in comparison to Guzerat bulls (Torres-Junior and Henry, 2005); TL was higher than that of Guzerat bulls (Torres-Junior and Henry, 2005) and lower than that of B. taurus indicus $\times$ B. taurus taurus bulls (Prieto et al., 2007). The TV was lower in comparison to Guzerat bulls (Torres-Junior and Henry, 2005).

\section{Seminal characteristics}

Ejaculate volume and seminal concentration significantly increased until the last evaluation (Table 3), which was when the bulls were one year older. The greatest ejaculate volume (EV) observed in both groups of bulls was similar to that of Holstein bulls in temperate climates (Brockettt et al., 1994) and B. taurus indicus $\times$ B. taurus taurus bulls (Prieto et al., 2007), and was higher than that of Criollo Limonero (Madrid et al., 1995), horned Costeño, and Romosinuano (Palmieri et al., 2004) bulls.

Spermatozoa concentration in CLT bulls was similar to that of Holstein bulls in a temperate climate (Brockettt et al., 1994) and Criollo Limonero bulls (Madrid et al., 1995) in a tropical climate, although it was lower than that of horned Costeño and Romosinuano (Palmieri et al., 2004) bulls, also in a tropical climate. Although the semen appearance coincided with that of this last study, the highest concentration of spermatozoa obtained in CLT bulls was around 1 billion $\mathrm{mL}^{-1}$, while in horned Costeño and Romosinuano (Palmieri et al., 2004) it was 1600 million $\mathrm{mL}^{-1}$. 
Table 3. Semen characteristics of young (G1) and mature (G2) Tropical Milking Criollo bulls during the study.

\begin{tabular}{|c|c|c|c|c|}
\hline \multirow{2}{*}{ Group } & \multicolumn{4}{|c|}{ Time periods } \\
\hline & 1 & 2 & 3 & 4 \\
\hline \multicolumn{5}{|c|}{ Semen volume $(\mathrm{mL})^{*}$} \\
\hline G1 & $3.4 \pm 0.2^{b}$ & $3.8 \pm 0.4^{b}$ & $3.3 \pm 0.4^{b}$ & $4.7 \pm 0.6^{\mathrm{a}}$ \\
\hline G2 & $3.8 \pm 0.6^{b}$ & $4.0 \pm 0.1^{b}$ & $5.5 \pm 0.8^{\mathrm{a}}$ & $6.5 \pm 1.4^{\mathrm{a}}$ \\
\hline \multicolumn{5}{|c|}{ Total sperm count $\left(\mathrm{x} 10^{6} \mathrm{~mL}^{-1}\right)^{*}$} \\
\hline G1 & $560 \pm 112^{b}$ & $586 \pm 103^{b}$ & $714 \pm 56^{\mathrm{b}}$ & $974 \pm 110^{a}$ \\
\hline G2 & $667 \pm 16^{b}$ & $667 \pm 167^{b}$ & $747 \pm 167^{b}$ & $1000 \pm 312^{a}$ \\
\hline \multicolumn{5}{|c|}{ Mass motility $(\%)^{*}$} \\
\hline G1 & $88 \pm 2$ & $88 \pm 2$ & $88 \pm 2$ & $84 \pm 4$ \\
\hline G2 & $80 \pm 2$ & $80 \pm 2$ & $80 \pm 2$ & $70 \pm 10$ \\
\hline \multicolumn{5}{|c|}{ Individual motility $(\%)^{*}$} \\
\hline G1 & $88 \pm 2$ & $88 \pm 2$ & $88 \pm 2$ & $84 \pm 4$ \\
\hline G2 & $80 \pm 2$ & $80 \pm 2$ & $80 \pm 2$ & $70 \pm 10$ \\
\hline \multicolumn{5}{|c|}{ Abnormal sperm $(\%)^{*}$} \\
\hline G1 & - & $12.0 \pm 1.2^{\mathrm{a}}$ & $13.4 \pm 0.9^{\mathrm{a}}$ & $6.6 \pm 0.7^{b}$ \\
\hline G2 & - & $13.3 \pm 1.7^{\mathrm{a}}$ & $16.3 \pm 0.9^{\mathrm{a}}$ & $3.7 \pm 0.3^{b}$ \\
\hline
\end{tabular}

a,b Means having different superscript letter within a row differed $(\mathrm{p}<0.05)$. * Mean \pm Standard deviation. 1=September 22 to December 20, 2=December 21 to March 19, 3=March 20 to June 20, 4=July 21 to September 21.

The MM and IM were high in CLT bulls from 19.3 \pm 0.4 months of age, contrary to reports that indicate that progressive motility gradually increases with age (TorresJúnior and Henry, 2005). The results indicate that CLT bulls show high MM and IM since a young age, which are maintained at least until 39.2 \pm 3.1 months of age. In CLT bulls IM was higher than that reported in Criollo Limonero (Madrid et al., 1995), horned Costeño, Romosinuano (Palmieri et al., 2004), Guzerat (Torres-Júnior and Henry, 2005), and B. taurus indicus $\times$ B. taurus taurus (Prieto et al., 2007) bulls.

The AE percentage in both groups of CLT bulls was less than $30 \%$, a value established as a minimum by the Society of Theriogenology. The AE percentage decreases as age increases (Torres-Júnior and Henry, 2005). The percentage of AE in young CLT bulls at 19.3 \pm 0.4 months of age was similar to that obtained at similar ages in Criollo Limonero (Madrid et al., 1995), and lower than that of horned Costeño, Romosinuano (Palmieri et al., 2004), and B. taurus indicus $\times$ B. taurus taurus (Prieto et al., 2007) bulls.

It is important to know the reproductive characteristics of the criollo breeds, in particular the CLT, in order to select the best specimens to be used to improve and increase the number of individuals of their breed, or in crossbreeding schemes with European or Zebu breeds in the tropics, to increase the profitability of the cattle herds in these regions and preserve this breed (Parra-Cortés and Magaña-Magaña, 2019).

\section{CONCLUSIONS}

The CLT bulls had good scrotal circumference and seminal quality from a young age through adulthood. The smaller scrotal circumference of the CLT breed, with respect 
to other breeds, does not affect its seminal quality and is in proportion to the smaller body size of these animals. The CLT bulls have similarities and differences with other breeds, for this reason, it is important to have specific information about this breed.

\section{REFERENCES}

Bailey, T. L., Monke, D., Hudson, R. S., Wolfe, D. F., Carson, R. L., \& Riddel, M. G. (1996). Testicular shape and its relationship to sperm production in mature Holstein bulls. Theriogenology, 46 (5): 881-887 p. Doi: 10.1016/s0093-691x(96)00245-2

Blom, E. (1973). The ultrastructure of some characteristic sperm defects and a proposal for a new classification of the bull spermiogram. Nordisk Veterinaer Medicin, 25 (7): 383-391p.

Brockett, C. C., Presicce, G. A., Foote, R. H., Kaproth, M. T., \& Rycroft, H. E. (1994). Semen quality and behavior of Holstein bulls exposed to estradiol-treated bulls for mounts. Journal of Dairy Science, 77 (1): 124-131p. Doi: 10.3168/jds.S00220302(94)76935-6

Coulter, G. H., Mapletoft, R.J., Kozub, G. C., \& Cates, W. F. (1987). Scrotal circumference of two-year-old bulls of several beef breeds. Theriogenology, 27 (3): 485-491p. Doi: 10.1016/0093-691X(87)90236-6

De Alba, J. (2011). Los Criollos Lecheros Tropicales. Montecillo, México: Colegio de Postgraduados.

Irons, P.C., Nöthling, J.O., Bertschinger, H.J. (2007). Bull breeden soundness evaluation in South Africa. Theryogenology, 68 (6): 842-847p. Doi:10.1016/j.theriogenology.2007.06.013

Jiménez-Severiano, H. (2002). Sexual development of dairy bulls in the Mexican tropics. Theriogenology, 58 (5): 921-932p. Doi: 10.1016/s0093-691x(02)00930-5

Madrid, N., Urdaneta, R., Bracho, I., Labbé, S., \& Aranguren, J. (1995). Desarrollo corporal, circunferencia escrotal y características seminales de toros Criollo Limonero en Venezuela. Revista Argentina de Producción Animal, 15: 967-968p.

Madrid-Bury, N., González-Stagnaro, C., Aranguren-Méndez, J. A., Yanez, F., \& Quintero-Moreno, A. (2011). Comportamiento sexual en toros criollo limonero. Revista de la Facultad de Agronomía de la Universidad de Zulia (LUZ), 28(1): 505-513p.

Martinez-Velázquez, G., Gregory, K.E., Bennett, G. L., \& Van Vleck, L. D. (2003). Genetic relationships between scrotal circumference and female reproductive traits. Journal of Animal Science, 81 (2): 395-401p. Doi: 10.2527/2003.812395x

Ocanto, D., Linares, T., Patiño, A., Ramos, C., \& Escobar, S. (1991). Índices de pubertad en bovinos machos Criollo Río Limón y Brahman. Zootecnia Tropical, 9: 25-54p.

Palmieri, R., Suárez, D., Espitia, A., González, M., \& Prieto, E. (2004) Variables seminales en toros criollos colombianos Costeño con cuernos y Romosinuano. Revista MVZ Córdoba, 9: 381-385p. Doi: 10.21897/rmvz.506

Parra-Cortés, R. I., \& Magaña-Magaña, M. A. (2019). Características técnico-económicas de los sistemas de producción bovina basados en razas criollas introducidas en México. Ecosistemas y Recursos Agropecuarios, 6 (18): 535-547. Doi: 10.19136/era. a6n18.2160

Prieto, E. M., Espitia, A. P., \& Cardozo, J. N. (2007). Efecto del invierno y verano sobre el comportamiento reproductivo de toros cruzados. Revista MVZ Córdoba, 12: 921-928p.

Rosendo-Ponce, A., \& Becerril-Pérez, C. M. (2015). Avance en el conocimiento del bovino Criollo Lechero Tropical de México. Ecosistemas y Recursos Agropecuarios, 2: 233-243p.

Silva, M. R., Pedroza, V. B., Silva, J. B. C., Herrera, L. G. G., Eler, J. P., \& Alburquerque, L. G. (2012). Parámetros genéticos de las características andrológicas de la especie bovina. Archivos de Medicina Veterinaria, 44 (1): 1-11. Doi: 10.4067/S0301$732 X 2012000100002$

Torres-Junior, J. R. S., \& Henry, M. (2005). Sexual development of Guzerat (Bos taurus indicus) bulls raised in a tropical region. Animal Reproduction, 2: 114-121. 
Vásquez, L., Arango J. (2002). Relación entre medidas corporales y desarrollo testicular en toretes Brahman peripuberales. Livestock Research for Rural Development, 14(5). http://ftp.sunet.se/wmirror/www.cipav.org.co/lrrd/lrrd14/5/vasq145.htm

Wildman, E. E., Jones, G. M., Wagner, P. E., Boman, R. L., Trout, J. R., \& Lesch, T. N. (1982). Dairy cow body condition scoring system and its relationship to selected production characteristics. Journal of Dairy Science, 65: 485-497. Doi: 10.3168/jds. S0022-0302(82)82223-6 